\title{
Purinergic Signaling in Liver Pathophysiology
}

\author{
Shanu Jain and Kenneth A. Jacobson* \\ Molecular Recognition Section, Laboratory of Bioorganic Chemistry, National Institute of Diabetes and Digestive and Kidney
} Diseases, Bethesda, MD, United States

Extracellular nucleosides and nucleotides activate a group of $\mathrm{G}$ protein-coupled receptors (GPCRs) known as purinergic receptors, comprising adenosine and P2Y receptors. Furthermore, purinergic P2X ion channels are activated by ATP. These receptors are expressed in liver resident cells and play a critical role in maintaining liver function. In the normal physiology, these receptors regulate hepatic metabolic processes such as insulin responsiveness, glycogen and lipid metabolism, and bile secretion. In disease states, ATP and other nucleotides serve as danger signals and modulate purinergic responses in the cells. Recent studies have demonstrated that purinergic receptors play a significant role in the development of metabolic syndrome associated non-alcoholic fatty liver disease

OPEN ACCESS

Edited by: Tobias Fromme,

Technical University of Munich,

Germany

Reviewed by:

Miles Douglas Thompson, University of California, San Diego, United States

Thorsten Gnad,

University Hospital Bonn, Germany

*Correspondence:

Kenneth A. Jacobson kennethj@niddk.nih.gov

Specialty section: This article was submitted to Cellular Endocrinology, a section of the journal Frontiers in Endocrinology

Received: 31 May 2021

Accepted: 26 July 2021

Published: 11 August 2021

Citation:

Jain S and Jacobson KA (2021)

Purinergic Signaling in Liver Pathophysiology.

Front. Endocrinol. 12:718429. doi: 10.3389/fendo.2021.718429 (NAFLD), non-alcoholic steatohepatitis (NASH), fibrosis, hepatocellular carcinoma (HCC) and liver inflammation. In this concise review, we dissect the role of purinergic signaling in different liver resident cells involved in maintaining healthy liver function and in the development of the above-mentioned liver pathologies. Moreover, we discuss potential therapeutic strategies for liver diseases by targeting adenosine, $\mathrm{P} 2 \mathrm{Y}$ and $\mathrm{P} 2 \mathrm{X}$ receptors.

Keywords: purinergic signaling, adenosine receptors, P2 receptors, hepatocyte, stellate cell

\section{INTRODUCTION}

The action of adenosine triphosphate (ATP) as an extracellular signaling molecule was initially proposed by Burnstock in $1972(1,2)$. ATP and its hydrolytic products (ADP and adenosine) along with other nucleotides and nucleotide sugars (UTP, UDP, UDP-glucose) act as extracellular signals to regulate various physiological and pathophysiological processes (3-7). These signaling molecules activate two families of purinoceptors: Adenosine receptors (also designated as P1) are activated principally by adenosine and consist of four subtypes shown as rodent gene name (subtype name): Adora1 $\left(A_{1} A R\right)$, Adora2a $\left(A_{2 A} A R\right)$, Adora2b $\left(A_{2 B} A R\right)$, Adora3 $\left(A_{3} A R\right)$. The adenosine receptors differ in their affinity for adenosine, with $A_{1} A R$ and $A_{2 A} A R$ exhibiting high affinity and $A_{3} A R$ and $A_{2 B} A R$ having lower affinity (8). $A_{1} A R$ and $A_{3} A R$ couple to $G_{i} / o$ proteins, whereas $A_{2 A} A R$ and $A_{2 B} A R$ couple to $G_{s / \text { olf }}$ proteins causing a decrease or increase in intracellular cAMP levels upon receptor activation respectively. $\mathrm{P} 2$ receptors are divided into ionotropic ligand-gated ion channel $\mathrm{P} 2 \mathrm{X}$ (P2X1-7, gene name P2rx\#), principally activated by ATP, and metabotropic G proteincoupled P2Y ( $\mathrm{P}_{2} \mathrm{Y}_{1,2,4,6,11,12,13,14}$, gene name P2ry\#) receptors. P2 $\mathrm{Y}_{1,2,4,6,11}$ receptors belong to the P2 $Y_{1}$-like subfamily and couple to $G_{q / 11}, G_{o}, G_{12 / 13}, G_{s}$ protein, whereas $P 2 Y_{12,13,14}$ receptors are classified as $\mathrm{P}_{2} \mathrm{Y}_{12}$-like and couple to $\mathrm{G}_{\mathrm{i} / \mathrm{o}}$ protein, thereby activating different intracellular signaling pathways. 
The liver is the largest internal organ in the body with a diverse range of functions including metabolism of glucose and other carbohydrates along with lipids, protein synthesis, detoxification, and bile secretion (9). The liver is a major site for nucleotide synthesis (salvage or de novo synthesis), and the release of these nucleotides into extracellular space may result in autocrine and paracrine activation of purinergic receptors on different cells, regulating various biological processes (10-12). ATP release can be mediated by various mechanisms such as exocytosis from lysosomes, unregulated release from necrotic cells, co-release with hormones, controlled release through connexin and pannexin hemichannels, and P2X7 ion channels (13-18). In this concise review, we will discuss the understanding of purinergic signaling in liver physiological and pathophysiological processes. We will also briefly describe potential clinical applications of purinergic signaling-based drugs for the therapeutics of liver disorders.

\section{SOURCES OF EXTRACELLULAR NUCLEOTIDES AND ADENOSINE IN LIVER}

Adenosine is produced in the extracellular space via dephosphorylation of ATP by a two-step enzymatic reaction sequence. First, CD39 (ecto-nucleoside triphosphate diphosphohydrolase 1: ENTPD1, NTPDase1) and NTPases convert ATP or ADP to AMP. In the second step, hydrolysis of AMP by CD73 (ecto-5'-nucleotidase: NT5E) results in the generation of the adenosine. The ectonucleotide pyrophosphatase/ phosphodiesterase (ENPP) family is also responsible for hydrolysis of extracellular nucleotides. The CD39-CD73-adenosine axis has been implicated in liver immune responses and inflammation related to various diseases (19). Intracellularly generated adenosine can also be transported across cell membranes by ENTs (equilibrative nucleoside transporters) and CNTs (concentrative nucleoside transporters). Vesicular nucleotide transporter (VNUT, SLC17A9) expressed by mouse hepatocytes has been shown to promote vesicular release of ATP and other nucleotides (20). VNUTdependent ATP release from the hepatocytes triggered postprandial triglyceride release and aggravated steatohepatitis in the liver (20). The authors also demonstrated that high blood glucose stimulated the release of ATP from hepatocytes, and this phenomenon was inhibited in mice lacking VNUT (20). Treatment of a mouse model of NASH with VNUT inhibitor (clodronate) reduced hepatic inflammation, fibrosis, and triglyceride accumulation (21). Another study demonstrated that human hepatocytes can release ATP in response to cell swelling or osmotic stress (22). Autocrine purinergic signaling mediated by ATP led to $\mathrm{Cl}^{-}$secretion that helped to recover the cell volume (22). Intrahepatic mechanical stress induced during hepatectomy resulted in the robust release of ATP from a lysosomal compartment of hepatocytes and Kupffer cells (23). This increased extracellular ATP levels promoted liver regeneration in the rat post-surgery (23). Connexin hemichannels required for the release of ATP have been implicated in steatohepatitis (24). Treatment of mice with connexin inhibitors (TAT-Gap24 and TAT-Gap19) decreased inflammatory markers and liver lipid levels while increasing superoxide dismutase levels (24). Another study demonstrated the role of pannexin1
(PANX1) in the pathogenesis of liver diseases (25). The mice lacking PANX1 displayed reduced inflammation compared to the control mice when induced with steatohepatitis (25). Selective deletion of CD39 has been studied by Robson and others (26). CD39 is beneficial during liver regeneration and for hepatic glucose metabolism. However, CD39 deletion in natural killer (NK) cells reduces interferon-g production to attenuate ischemia/reperfusion injury in mouse liver. Hence, extracellular nucleotides and purinergic signaling have been implicated in the regulation of various hepatic processes (26-29).

\section{LIVER - A METABOLIC ORGAN}

The liver is a key organ for the regulation of glucose homeostasis in both fed and fasted conditions $(30,31)$. During fasting, stored glycogen in the liver is broken down by the process of glycogenolysis to maintain normoglycemia. The liver also contributes to fasting glucose production by the process of gluconeogenesis. The net hepatic glucose output helps to provide an energy source to extrahepatic tissues during starvation $(30,31)$. Starvation also promotes the accumulation of lipids (triacylglycerol (TAG) and diacylglycerol (DAG)) in the liver. These key liver functions are mainly performed by parenchymal cells termed hepatocytes (30). Hepatocytes make up to roughly $80 \%$ of the total hepatic mass. In addition to the parenchymal cells, the liver contains nonparenchymal cells, i.e. hepatic stellate cells (HSC, fat-storing pericytes located between a sinusoidal capillary and hepatocytes), cholangiocytes (bile duct epithelial cells) and Kupffer (resident macrophages), vascular endothelial and smooth muscle cells, that through crosstalk with hepatocytes and with each other regulate liver functions $(31,32)$. Many non-resident cells infiltrating into the liver such as macrophages, neutrophils, dendritic cells, natural killer cells, and $\mathrm{T}$ and $\mathrm{B}$ lymphocytes regulate cytokine production affecting liver metabolic activity in pathophysiological conditions (32). Most of the liver cell types (both resident and infiltrating) express multiple purinergic receptor subtypes (32).

\section{HEPATIC CARBOHYDRATE AND LIPID METABOLISM}

Purinergic signaling plays a role in various processes related to carbohydrate and lipid metabolism in the liver. Mechanical stimulation, stress such as hypoxia, or cell lysis may cause the release of nucleotides, such as ATP and UTP, by hepatocytes (and consequently elevated adenosine) that induce $\mathrm{Ca}^{2+}$-mediated glycogenolysis in neighboring hepatocytes (11). Extracellular ATP stimulates glycogenolysis in hepatocytes and perfused livers (33-36). Treatment of human hepatocytes with BzATP, a P2XR agonist, decreases glycogen content (37). Mechanistically, stimulation of $\mathrm{P} 2 \mathrm{X}$ resulted in $\mathrm{Ca}^{2+}$-mediated activation of glycogen phosphorylase, a rate-limiting enzyme in the glycogenolysis pathway (37-39). In the perfused liver, UTP induces glycogenolysis more potently than ATP due to its robust effect on thromboxane secretion from the non-parenchymal cell (40). ATP also enhances $\mathrm{Ca}^{2+}$-mediated gluconeogenesis in 
hepatocytes $(41,42)$. However, high concentrations of ATP inhibit gluconeogenesis from sources such as pyruvate and lactate (43). Stimulation of cultured hepatocytes by ATP attenuates glycolysis, through inhibition of phosphofructokinase-2 (44). Activation of $\mathrm{A}_{1} \mathrm{AR}$ enhanced $\mathrm{Ca}^{2+}$-mediated glycogenolysis in isolated rat hepatocytes (45). The authors also showed that activation of $\mathrm{A}_{2 \mathrm{~A}} \mathrm{R}$ with a selective agonist (CGS21680) also promoted glucose release via gluconeogenesis in rat hepatocytes (45).

Nucleotides also regulate liver lipid metabolism. Extracellular ATP inhibits acetyl-CoA carboxylase (ACC) by elevating intracellular calcium levels in rat hepatocytes (46). ATP treatment also simultaneously inhibited carnitine O-palmitoyltransferase I (CPT-1) activity through a PKC-dependent mechanism (46). $\mathrm{A}_{2 \mathrm{~A}} \mathrm{R}$ deficiency enhanced expression and activity of lipogenic gene-sterol regulatory element-binding protein 1c (SREBP1c) in mouse hepatocytes (47). Extracellular nucleotides were also reported to play a key role in reverse cholesterol transport. Chronic activation of $\mathrm{P} 2 \mathrm{Y}_{13} \mathrm{R}$ by a partial agonist (AR-C69931MX) increased liver uptake of cholesterol (48). Further, a study on $\mathrm{P}_{2} \mathrm{Y}_{13} \mathrm{R}$ deficient mice displayed impaired features of reverse cholesterol transport, independent of plasma HDL levels $(49,50)$.

\section{PURINERGIC SIGNALING IN LIVER METABOLIC DISORDERS}

\section{Non-Alcoholic Fatty Liver Disease and Non-Alcoholic Steatohepatitis}

Metabolic syndrome and non-alcoholic fatty liver disease (NAFLD) have a bidirectional mutual relationship, suggesting that the occurrence of one can enhance the severity of the other. The effect of metabolic syndrome on NAFLD may be greater than the effects of NAFLD on metabolic syndrome $(51,52)$. Metabolic syndrome characterized by obesity, insulin resistance, dyslipidemia, and glucose tolerance can initiate ectopic deposition of lipids in the liver causing NAFLD (52). NAFLD can progress to non-alcoholic steatohepatitis (NASH), a severe form of NAFLD associated with liver inflammation (53). Studies have been conducted showing the effects of purinergic receptors directly on liver dysfunction or indirectly via improving features of metabolic syndrome. The liver of streptozotocin (STZ)-induced diabetic rats showed increased adenosine $\mathrm{A}_{1} \mathrm{AR}$ expression (54). However, a different study claimed no change in $A_{1} A R$ expression, whereas expression of $\mathrm{A}_{2 \mathrm{~A}} \mathrm{AR}$ and $\mathrm{A}_{3} \mathrm{AR}$ receptors was significantly upregulated in STZtreated rat liver (55). P2X7R expression was increased in hepatocytes, Kupffer cells, and liver sinusoidal endothelial cells in the NASH disease model (56). Lack of P2X7R ameliorates hepatocyte apoptosis and decreases inflammation and fibrosis in mice treated with carbon tetrachloride $\left(\mathrm{CCl}_{4}\right)$ with a high fat diet (HFD) $(56,57)$. Activation of P2X7R on Kupffer cells enhances the production of TNF- $\alpha$ and monocyte chemotactic protein-2 (MCP-2) production in HFD mice treated with $\mathrm{CCl}_{4}$ (57). These studies suggest that P2X7R antagonists may prove useful for the treatment of NASH.

$\mathrm{A}_{2 \mathrm{~A}} \mathrm{AR}$ activation has an anti-inflammatory effect $(58,59)$, whereas its deficiency increases pro-inflammatory responses
(60). Further, the lack of whole-body $\mathrm{A}_{2 \mathrm{~A}} \mathrm{AR}$ in mice enhanced HFD-induced NAFLD and liver inflammation (47). Accordingly, deficiency of $\mathrm{A}_{2 \mathrm{~A}} \mathrm{AR}$ in hepatocytes and macrophages contributed to enhanced inflammation (47). The effect of $\mathrm{A}_{2 \mathrm{~A}} \mathrm{AR}$ on inflammation was also demonstrated in the methionine- and choline-deficient (MCD)-induced NASH mouse model. The MCD-NASH mouse model combined with $\mathrm{A}_{2 \mathrm{~A}} \mathrm{AR}$ knockout (KO) exhibited higher body weight, enhanced liver inflammation, and severe hepatic steatosis than the control group (61). The $\mathrm{A}_{2 \mathrm{~A}} \mathrm{AR}$ 's role in reducing inflammation caused by lipotoxicity substantially imparted protection against the development of NASH $(62,63)$. These studies suggest the therapeutic potential of $\mathrm{A}_{2 \mathrm{~A}} \mathrm{AR}$ agonists in decreasing inflammation associated with NAFLD/NASH and metabolic syndrome (Figure 1).

$\mathrm{A}_{2 \mathrm{~B}} \mathrm{AR}$ was also demonstrated to play a critical role in regulating fatty liver disease. Deficiency of $\mathrm{A}_{2 \mathrm{~B}} \mathrm{AR}$ protected mice from hepatic steatosis and development of fatty liver (64). Inhibition of $\mathrm{A}_{2 \mathrm{~B}} \mathrm{AR}$ by selective antagonist ATL-801 in diabetic $\mathrm{KKA}(\mathrm{Y})$ mice reduced glucose output during hyperinsulinemiceuglycemic clamp studies (65). Some of the contrasting studies showed that $A_{2 B} A R$ activation inhibited lipogenic genes such as sterol regulatory element-binding protein-1 (SREBP-1). HFD mice lacking $\mathrm{A}_{2 \mathrm{~B}} \mathrm{AR}$ displayed hepatic steatosis with enhanced plasma triglyceride and cholesterol levels (66). Furthermore, overexpression and activation of hepatic $\mathrm{A}_{2 \mathrm{~B}} \mathrm{AR}$ reduced lipid synthesis in the liver and improved whole-body metabolism (66). $\mathrm{A}_{2 \mathrm{~B}} \mathrm{AR} \mathrm{KO}$ mice on regular diet showed reduced weight and increased de novo lipogenesis resulting in elevated liver triglyceride levels. Increased mRNA levels of glucokinase and fatty acid synthase confirmed impaired lipid metabolism in the liver of $\mathrm{A}_{2 \mathrm{~B}} \mathrm{AR} \mathrm{KO}$ mice (67). HFD $\mathrm{A}_{2 \mathrm{~B}} \mathrm{AR} \mathrm{KO}$ mice exhibited impaired glucose tolerance and insulin sensitivity (68). Wild type (WT) mice treated with $\mathrm{A}_{2 \mathrm{~B}} \mathrm{AR}$ agonist/partial agonist (BAY60$6553)$ displayed improved glucose and insulin tolerance and decreased fasting blood glucose levels (68). These observations render $\mathrm{A}_{2 \mathrm{~B}} \mathrm{AR}$ a good drug target for the treatment of liver diseases (Figure 1).

Recent studies have highlighted the importance of the $A_{3} A R$ in NAFLD/NASH. $A_{3} A R$ expression in livers from NAFLD patients was decreased by 1.9-fold compared to controls, highlighting a plausible role of the receptor in NAFLD pathophysiology (69). Global deficiency of $\mathrm{A}_{3} \mathrm{AR}$ in mice fed a HFD enhanced expression of genes involved in hepatic inflammation and steatosis (69) (Figure 1). The authors showed that administration of an $\mathrm{A}_{3} \mathrm{AR}$ agonist prodrug (MRS7476, $5 \mathrm{mg} / \mathrm{kg}$, p.o., b.i.d.) protected the STAM mouse model against the development of NASH (69). The two succinyl ester groups of MRS7476 greatly increase its water solubility and are likely cleaved in the gut, rather than the site of action. Another study showed the efficacy of $\mathrm{A}_{3} \mathrm{AR}$ agonist Cl-IBMECA (namodenoson) in the treatment of NASH in mice (70). The drug namodenoson is currently in Phase 2 clinical trials for NASH therapeutics (ClinicalTrials.gov Identifiers: NCT02927314 and NCT04697810, accessed 05-31-2021).

Obesity is a key risk factor for the development of NAFLD, and hence the mainstay treatment for NAFLD and NASH is 


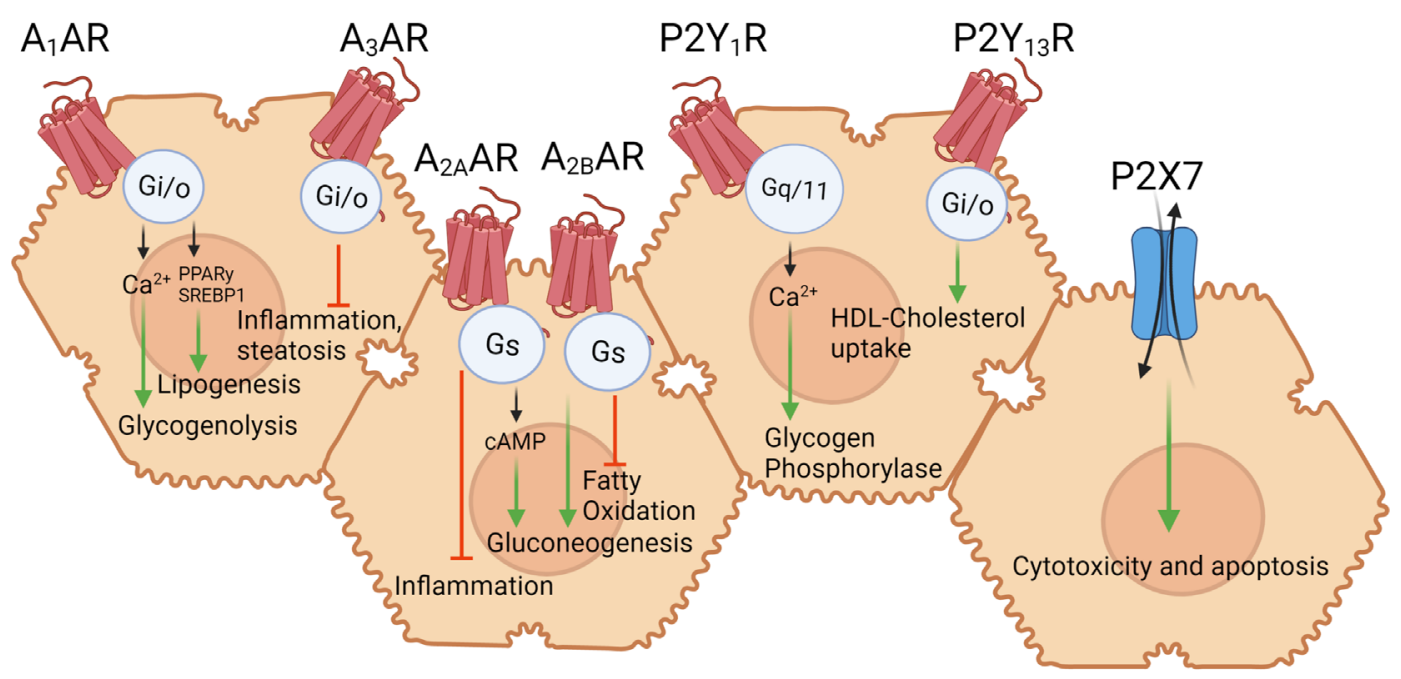

Hepatocyte

FIGURE 1 | Purinergic signaling in hepatocytes. Hepatocytes are parenchymal cells of the liver and are involved in maintaining whole-body glucose and lipid homeostasis. Hepatocytes express various purinergic receptors that play a key role in regulating glucose, lipid, cholesterol metabolism, and hepatocyte apoptosis.

weight loss. Recent studies have demonstrated the role of P2Y receptors in regulating obesity and its impact on liver steatosis and inflammation. Mice lacking $\mathrm{P}_{2} \mathrm{Y}_{6} \mathrm{R}$ selectively in adipocytes were protected from diet-induced obesity (without a significant change in food intake) and systemic inflammation (71). Reduced obesity in adipocyte- $\mathrm{P} 2 \mathrm{Y}_{6} \mathrm{R} \mathrm{KO}$ resulted in lower liver weight and hepatic steatosis (71). Further, mRNA levels of inflammatory markers were reduced in the liver of adipocyte $\mathrm{P} 2 \mathrm{Y}_{6} \mathrm{R}$ KO mice (71). Another study revealed that mice lacking $\mathrm{P} 2 \mathrm{Y}_{14} \mathrm{R}$ selectively in adipocytes were protected from obesity and displayed reduced liver weight compared to HFD control mice (72). Liver triglyceride levels were significantly reduced in adipocyte $\mathrm{P}_{2} \mathrm{Y}_{14} \mathrm{R} \mathrm{KO}$ mice, protecting mice from the development of liver steatosis (72). Reduced obesity and hepatic steatosis further contributed to improved insulin sensitivity in the liver of adipocyte- $\mathrm{P} 2 \mathrm{Y}_{14} \mathrm{R} \mathrm{KO}$ mice (72). These studies highlight that blocking $\mathrm{P}_{2} \mathrm{Y}_{6} \mathrm{R}$ and $\mathrm{P} 2 \mathrm{Y}_{14} \mathrm{R}$ in adipocytes protects against dietinduced obesity (DIO) and hence has the potential to treat NAFLD/NASH (Figure 2).

\section{Liver Fibrosis}

Repetitive injury or inflammation due to NAFLD/NASH causes scarring of liver tissue or fibrosis $(73,74)$. Untreated fibrosis can lead to irreversible liver damage and progress to liver cirrhosis. Hepatic fibrosis is characterized by the accumulation of extracellular matrix due to activation and differentiation of hepatic stellate cells (HSC) into fibrogenic myofibroblasts (74). Purinergic receptors have been implicated in the regulation of HSC activation. Activation of $\mathrm{A}_{2 \mathrm{~A}} \mathrm{AR}$ induced proliferation and reduced apoptosis and senescence of rat primary HSC and the human HSC cell line LX-2 (Figure 3). Mechanistically, $\mathrm{A}_{2 \mathrm{~A}} \mathrm{AR}$ activation down-regulates $\mathrm{p} 53$ and retinoblastoma $(\mathrm{Rb})$ protein levels (both tumor suppressors), enhancing HSC survival and contributing to liver fibrosis (75). An $\mathrm{A}_{2 \mathrm{~A}} \mathrm{R}$ antagonist may prove useful in the treatment of ethanol-induced liver fibrosis and HSC activation (76). An $\mathrm{A}_{2 \mathrm{~B}} \mathrm{AR}$ antagonist (MRS1754) has shown promising results in mitigating collagen deposition during hepatic fibrosis progression (77).

Quiescent HSCs with low levels of proliferation and decreased extracellular matrix deposition express $\mathrm{P} 2 \mathrm{Y}_{2} \mathrm{R}$ and $\mathrm{P} 2 \mathrm{Y}_{4} \mathrm{R}$, whereas activated HSCs expressed $\mathrm{P}_{2} \mathrm{Y}_{6} \mathrm{R}$ (78). Treatment of activated HSCs with UDP (native $\mathrm{P}_{2} \mathrm{Y}_{6} \mathrm{R}$ agonist) tripled the mRNA levels of procollagen-1, indicating that $\mathrm{P} 2 \mathrm{Y}_{6} \mathrm{R}$ may play a role in liver fibrosis (78) (Figure 3). P2X7R expression levels also increased significantly in activated HSCs, promoting proliferation and collagen production (79). P2X7R expression is enhanced in mouse models of liver fibrosis treated with $\mathrm{CCl}_{4}$ and treatment with a P2X7R antagonist (A438079) decreased liver inflammation and collagen accumulation (80). P2X4R expression was increased in the MCDD liver fibrosis mouse model (81). Deficiency of P2X4 or treatment with the 5-BDBD (a $\mathrm{P} 2 \mathrm{X} 4 \mathrm{R}$ antagonist) protected mice from MCDD-induced liver fibrosis (81).

Activity of CD73, ecto-5'-nucleotidase, was higher in quiescent HSCs than the activated HSCs, indicating that adenosine may play a key role in maintaining the quiescent phenotype of HSCs (82). However, a recent study showed that CD73 expression increased in differentiated myofibroblast and may be targeted for fibrosis treatment (83). Lack of CD73 protected mice against $\mathrm{CCl}_{4^{-}}$and thioacetamide (TAA)induced liver fibrosis (84).

\section{Liver Cancer}

Liver fibrosis and cirrhosis can progress to the development of liver cancer associated with chronic inflammation, dysfunctional metabolism and immune responses, and aberrant cell 

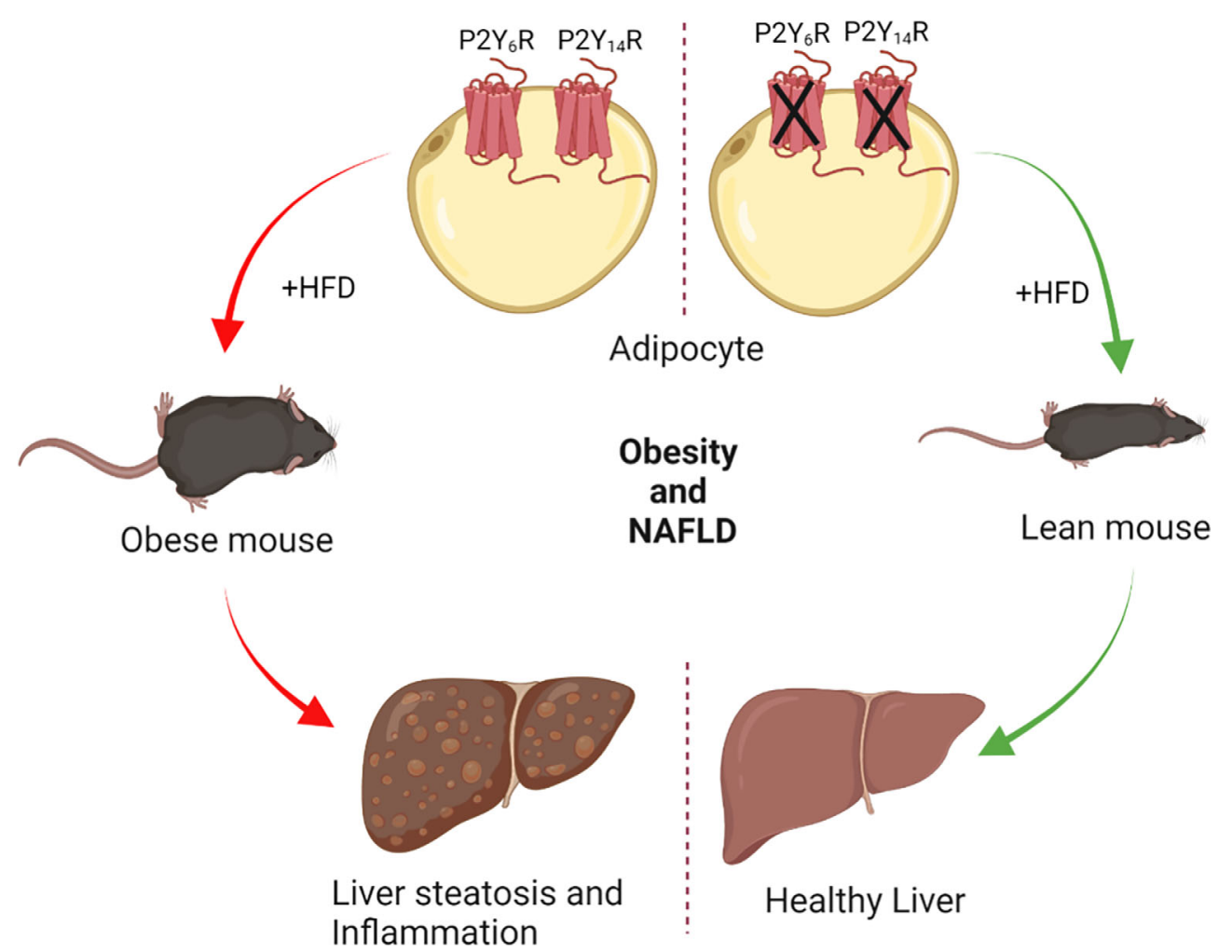

FIGURE 2 | Dysregulated purinergic signaling in adipocytes alleviates obesity and associated NAFLD. Lack of P2Y ${ }_{6} R$ or $P 2 Y_{14} R$ specifically in adipocytes protects against diet-induced obesity. Reduced fat mass prevented the ectopic deposition of lipids in the liver, decreasing hepatic steatosis. Hepatic inflammation was reduced in mice lacking $P 2 Y_{6} R$ or $P 2 Y_{14} R$ in adipocytes. Antagonists of $P 2 Y_{6} R$ and $P 2 Y_{14} R$ may prove beneficial for the treatment of obesity-associated NAFLD.

proliferation (85). ATP released from the necrotic cells acts as a danger signal to activate immune cells during cancer development and stimulate neighboring cells to die. Change in the concentration of extracellular ATP from $1 \mathrm{mM}$ to $2.5 \mathrm{mM}$ tipped the balance from mechanistic target of rapamycin (mTOR)-mediated autophagy required for cell survival to AMP-activated kinase (AMPK)-mediated apoptosis-induced cell death in hepatoma cells (86). This study provides evidence for the manipulation of extracellular ATP for cancer therapy. Extracellular ATP causes increased expression of purinergic receptors in hepatic tumor tissue compared to healthy liver tissue (87-89). $\mathrm{P}_{2} \mathrm{Y}_{11} \mathrm{R}$ receptor is expressed at very high levels in human hepatocellular carcinoma (HCC) tissues and was scarcely detected in normal liver tissues (89). $\mathrm{P} 2 \mathrm{Y}_{11} \mathrm{R}$ mediates ATP-induced $\mathrm{Ca}^{2+}$ signaling and cell migration in human HCC cells (89). Accordingly, treatment with a $\mathrm{P}_{2} \mathrm{Y}_{11} \mathrm{R}$ antagonist (NF340) attenuated the effects of ATP on HCC cells (89). ATP-induced activation of $\mathrm{P}_{2} \mathrm{Y}_{2} \mathrm{R}$ mediates the proliferation and migration of human HCC cells (90). Knockdown of $\mathrm{P}_{2} \mathrm{Y}_{2} \mathrm{R}$ expression by shRNA inhibited the action of ATP on the cellular behavior of HCC cells (90). These studies indicate that blocking $\mathrm{P}_{2} \mathrm{Y}_{11} \mathrm{R}$ and $\mathrm{P}_{2} \mathrm{Y}_{2} \mathrm{R}$ signaling may prevent the proliferation and migration of cancerous cells and may be useful for the treatment of liver cancer.
CD39 (ectonucleoside triphosphate diphosphohydrolase-1, ENTPD1) deficiency increases ATP levels activating AMPK and mTOR pathways to stimulate hepatocyte proliferation (91). CD73 is a prognostic marker of HCC as it is expressed highly in around $50 \%$ of HCC samples compared to the healthy tissues (92). CD73 activity increase HCC growth and metastasis via promoting $\mathrm{PI} 3 \mathrm{~K} / \mathrm{AKT}$ signaling in vivo $(92,93)$. Blocking CD73 with $\alpha, \beta$-methylene-ADP (AMPCP) or $\mathrm{A}_{2 \mathrm{~A}} \mathrm{AR}$ with istradefylline (KW6002, now FDA-approved for Parkinson's disease treatment) inhibited tumor growth (92). Co-treatment with CD73 and $\mathrm{A}_{2 \mathrm{~A}} \mathrm{AR}$ inhibitors displayed synergistic effects on HCC cells (92). High expression of $A_{3} A R$ was also reported in tumor tissues and peripheral blood mononuclear cells from patients suffering from $\mathrm{HCC}(94,95)$. Treatment with $\mathrm{A}_{3} \mathrm{AR}$ agonist (CF102) promotes apoptosis and inhibits the growth of HCC cells in a dose-dependent manner $(94,95)$.

\section{CONCLUSIONS}

This review has highlighted the developing role of purinergic receptors in the regulation of hepatic disorders associated with metabolic syndrome. Among adenosine receptors, preclinical studies have highlighted the key role of $\mathrm{A}_{3} \mathrm{AR}$ agonists in protecting against NASH. $\mathrm{A}_{3} \mathrm{AR}$ agonist may also be useful in 


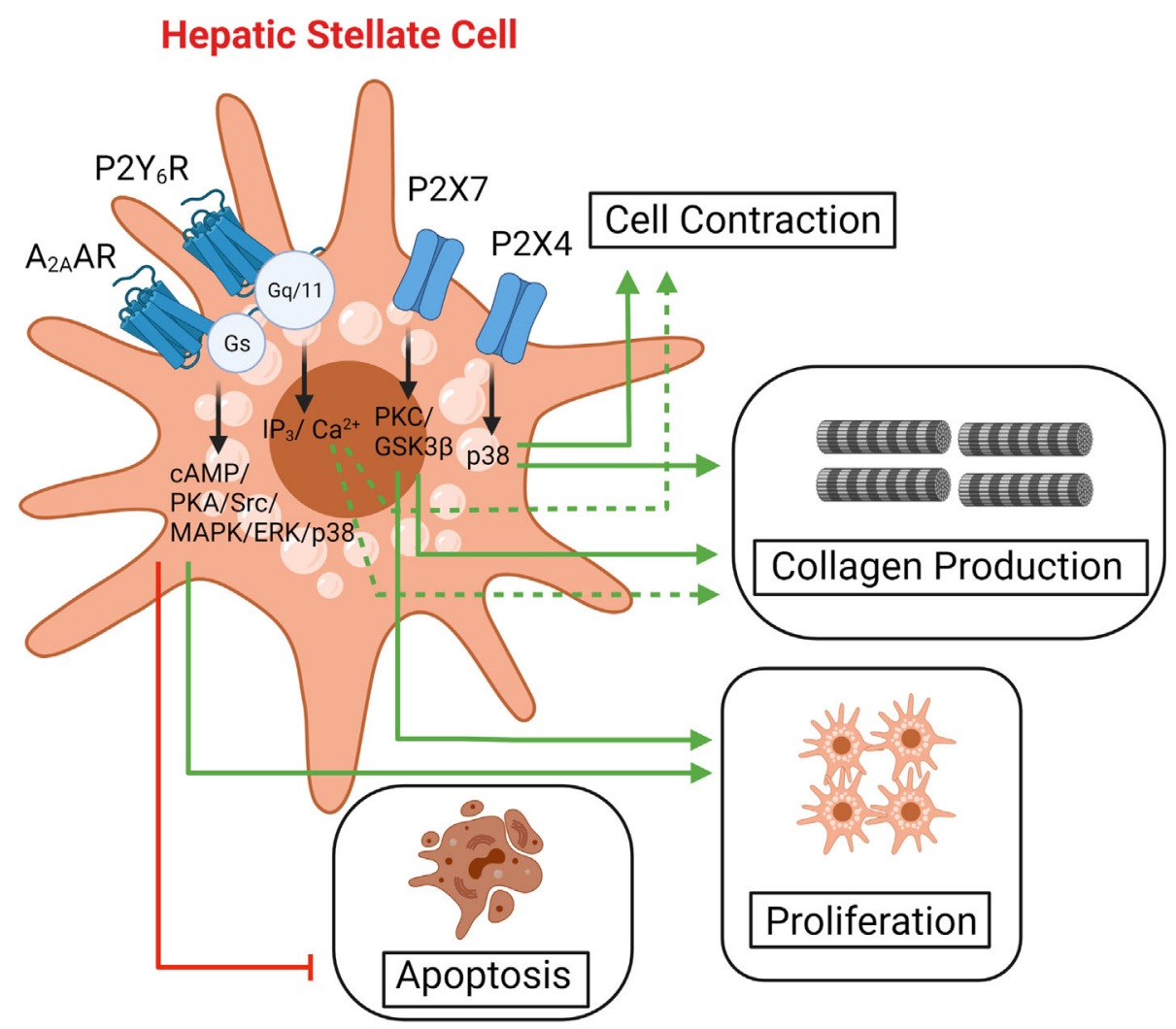

FIGURE 3 | Purinergic signaling in hepatic stellate cells. Hepatic stellate cells (HSC) are classified as non-parenchymal cells of the liver. HSC activation and proliferation results in the secretion of extracellular matrix causing liver fibrosis. Purinergic receptors are expressed in HSC and regulate key processes associated with the initiation and progression of liver fibrosis.

preventing the growth of liver cancer. $\mathrm{A}_{2 \mathrm{~A}} \mathrm{AR}$ and $\mathrm{A}_{2 \mathrm{~B}} \mathrm{AR}$ antagonists may provide therapeutic benefits against liver fibrosis. Among $\mathrm{P} 2 \mathrm{Y}$ receptors, $\mathrm{P}_{2} \mathrm{Y}_{6} \mathrm{R}$ or $\mathrm{P}_{2} \mathrm{Y}_{14} \mathrm{R}$ antagonist may prove beneficial in preventing NAFLD and hepatic inflammation associated with obesity. P2X7R receptors antagonist can be examined for the treatment of NASH and liver fibrosis. Most of the previous studies have focused on whole-body KO mouse models or pharmacological manipulation for studying purinergic signaling effects on liver metabolism. Studies on understanding the role of purinergic receptors in the liver pathophysiology using liver cell-specific KO mouse are lacking. Future studies using liver-specific KO mouse models for understanding liver diseases are warranted. Numerous potent ligands for purinergic receptors have been synthesized that can be tested in preclinical mouse models of liver diseases (96-103). Characterization of agonists and

\section{REFERENCES}

1. Burnstock G, Campbell G, Satchell D, Smythe A. Evidence That Adenosine Triphosphate or a Related Nucleotide Is the Transmitter Substance Released by Non-Adrenergic Inhibitory Nerves in the Gut. Br J Pharmacol (1970) 40 (4):668-88. doi: 10.1111/j.1476-5381.1970.tb10646.x antagonists for purinergic receptors in preclinical mouse models may foster the development of novel drugs for the treatment of liver diseases.

\section{AUTHOR CONTRIBUTIONS}

Conceptualization: SJ and KJ. SJ wrote the first draft. Writing: KJ. All authors contributed to the article and approved the submitted version.

\section{FUNDING}

Support from the NIDDK Intramural Research Program (ZIADK31116, ZIAKD31117) is acknowledged. 
5. Antonioli L, Blandizzi C, Pacher P, Hasko G. Immunity, Inflammation and Cancer: A Leading Role for Adenosine. Nat Rev Cancer (2013) 13(12):84257. doi: $10.1038 / \mathrm{nrc} 3613$

6. Gnad T, Scheibler S, von Kugelgen I, Scheele C, Kilic A, Glode A, et al. Adenosine Activates Brown Adipose Tissue and Recruits Beige Adipocytes via $\mathrm{A}_{2 \mathrm{~A}}$ Receptors. Nature (2014) 516(7531):395-9. doi: 10.1038/ nature 13816

7. Gnad T, Navarro G, Lahesmaa M, Reverte-Salisa L, Copperi F, Cordomi A, et al. Adenosine/ $\mathrm{A}_{2 \mathrm{~B}}$ Receptor Signaling Ameliorates the Effects of Aging and Counteracts Obesity. Cell Metab (2020) 32(1):56-70.e7. doi: 10.1016/ j.cmet.2020.06.006

8. Fredholm BB. Adenosine-a Physiological or Pathophysiological Agent? J Mol Med (Berl) (2014) 92(3):201-6. doi: 10.1007/s00109-013-1101-6

9. Rui L. Energy Metabolism in the Liver. Compr Physiol (2014) 4(1):177-97. doi: $10.1002 /$ cphy.c130024

10. Fustin JM, Doi M, Yamada H, Komatsu R, Shimba S, Okamura H. Rhythmic Nucleotide Synthesis in the Liver: Temporal Segregation of Metabolites. Cell Rep (2012) 1(4):341-9. doi: 10.1016/j.celrep.2012.03.001

11. Schlosser SF, Burgstahler AD, Nathanson MH. Isolated Rat Hepatocytes can Signal to Other Hepatocytes and Bile Duct Cells by Release of Nucleotides. Proc Natl Acad Sci USA (1996) 93(18):9948-53. doi: 10.1073/ pnas.93.18.9948

12. Dranoff JA, Nathanson MH. It's Swell to Have ATP in the Liver. J Hepatol (2000) 33(2):323-5. doi: 10.1016/S0168-8278(00)80374-8

13. MacDonald PE, Braun M, Galvanovskis J, Rorsman P. Release of Small Transmitters Through Kiss-and-Run Fusion Pores in Rat Pancreatic Beta Cells. Cell Metab (2006) 4(4):283-90. doi: 10.1016/j.cmet.2006.08.011

14. Zhang Z, Chen G, Zhou W, Song A, Xu T, Luo Q, et al. Regulated ATP Release From Astrocytes Through Lysosome Exocytosis. Nat Cell Biol (2007) 9(8):945-53. doi: $10.1038 /$ ncb1620

15. Chekeni FB, Elliott MR, Sandilos JK, Walk SF, Kinchen JM, Lazarowski ER, et al. Pannexin 1 Channels Mediate 'Find-Me' Signal Release and Membrane Permeability During Apoptosis. Nature (2010) 467(7317):863-7. doi: 10.1038/nature09413

16. Elliott MR, Chekeni FB, Trampont PC, Lazarowski ER, Kadl A, Walk SF, et al. Nucleotides Released by Apoptotic Cells Act as a Find-Me Signal to Promote Phagocytic Clearance. Nature (2009) 461(7261):282-6. doi: 10.1038/nature08296

17. Anselmi F, Hernandez VH, Crispino G, Seydel A, Ortolano S, Roper SD, et al. ATP Release Through Connexin Hemichannels and Gap Junction Transfer of Second Messengers Propagate Ca2+ Signals Across the Inner Ear. Proc Natl Acad Sci USA (2008) 105(48):18770-5. doi: 10.1073/ pnas. 0800793105

18. Faigle M, Seessle J, Zug S, El Kasmi KC, Eltzschig HK. ATP Release From Vascular Endothelia Occurs Across Cx43 Hemichannels and is Attenuated During Hypoxia. PLoS One (2008) 3(7):e2801. doi: 10.1371/ journal.pone.0002801

19. Wang S, Gao S, Zhou D, Qian X, Luan J, Lv X. The Role of the CD39-CD73Adenosine Pathway in Liver Disease. J Cell Physiol (2021) 236(2):851-62. doi: $10.1002 /$ jcp. 29932

20. Tatsushima K, Hasuzawa N, Wang L, Hiasa M, Sakamoto S, Ashida K, et al. Vesicular ATP Release From Hepatocytes Plays a Role in the Progression of Nonalcoholic Steatohepatitis. Biochim Biophys Acta Mol Basis Dis (2021) 1867(3):166013. doi: 10.1016/j.bbadis.2020.166013

21. Hasuzawa N, Tatsushima K, Wang L, Kabashima M, Tokubuchi R, Nagayama A, et al. Clodronate, an Inhibitor of the Vesicular Nucleotide Transporter, Ameliorates Steatohepatitis and Acute Liver Injury. Sci Rep (2021) 11(1):5192. doi: 10.1038/s41598-021-83144-w

22. Feranchak AP, Fitz JG, Roman RM. Volume-Sensitive Purinergic Signaling in Human Hepatocytes. J Hepatol (2000) 33(2):174-82. doi: 10.1016/S01688278(00)80357-8

23. Gonzales E, Julien B, Serriere-Lanneau V, Nicou A, Doignon I, Lagoudakis L, et al. ATP Release After Partial Hepatectomy Regulates Liver Regeneration in the Rat. J Hepatol (2010) 52(1):54-62. doi: 10.1016/j.jhep.2009.10.005

24. Willebrords J, Cogliati B, Pereira IVA, da Silva TC, Crespo Yanguas S, Maes $\mathrm{M}$, et al. Inhibition of Connexin Hemichannels Alleviates non-Alcoholic Steatohepatitis in Mice. Sci Rep (2017) 7(1):8268. doi: 10.1038/s41598-01708583-w
25. Willebrords J, Maes M, Pereira IVA, da Silva TC, Govoni VM, Lopes VV, et al. Protective Effect of Genetic Deletion of Pannexin1 in Experimental Mouse Models of Acute and Chronic Liver Disease. Biochim Biophys Acta Mol Basis Dis (2018) 1864(3):819-30. doi: 10.1016/j.bbadis.2017.12.013

26. Velazquez-Miranda E, Diaz-Munoz M, Vazquez-Cuevas FG. Purinergic Signaling in Hepatic Disease. Purinergic Signal (2019) 15(4):477-89. doi: 10.1007/s11302-019-09680-3

27. Vaughn BP, Robson SC, Burnstock G. Pathological Roles of Purinergic Signaling in the Liver. J Hepatol (2012) 57(4):916-20. doi: 10.1016/ j.jhep.2012.06.008

28. Burnstock G, Vaughn B, Robson SC. Purinergic Signalling in the Liver in Health and Disease. Purinergic Signal (2014) 10(1):51-70. doi: 10.1007/ s11302-013-9398-8

29. Vaughn BP, Robson SC, Longhi MS. Purinergic Signaling in Liver Disease. Dig Dis (2014) 32(5):516-24. doi: 10.1159/000360498

30. Roden M, Shulman GI. The Integrative Biology of Type 2 Diabetes. Nature (2019) 576(7785):51-60. doi: 10.1038/s41586-019-1797-8

31. Trefts E, Gannon M, Wasserman DH. The Liver. Curr Biol (2017) 27(21): R1147-R51. doi: 10.1016/j.cub.2017.09.019

32. Wang P, Jia J, Zhang D. Purinergic Signalling in Liver Diseases: Pathological Functions and Therapeutic Opportunities. JHEP Rep (2020) 2(6):100165. doi: 10.1016/j.jhepr.2020.100165

33. Haussinger D, Stehle T, Gerok W. Actions of Extracellular UTP and ATP in Perfused Rat Liver. A Comparative Study. Eur J Biochem (1987) 167(1):6571. doi: 10.1111/j.1432-1033.1987.tb13304.x

34. Keppens S, De Wulf H. P2-Purinergic Control of Liver Glycogenolysis. Biochem J (1985) 231(3):797-99. doi: 10.1042/bj2310797

35. Keppens S, De Wulf H. Characterization of the Liver P2-Purinoceptor Involved in the Activation of Glycogen Phosphorylase. Biochem J (1986) 240(2):367-71. doi: 10.1042/bj2400367

36. Keppens S, Vandekerckhove A, De Wulf H. Characterization of the Purinoceptors Present in Rabbit and Guinea Pig Liver. Eur J Pharmacol (1990) 182(1):149-53. doi: 10.1016/0014-2999(90)90504-Y

37. Emmett DS, Feranchak A, Kilic G, Puljak L, Miller B, Dolovcak S, et al. Characterization of Ionotrophic Purinergic Receptors in Hepatocytes. Hepatology (2008) 47(2):698-705. doi: 10.1002/hep.22035

38. Dixon CJ, White PJ, Hall JF, Kingston S, Boarder MR. Regulation of Human Hepatocytes by P2Y Receptors: Control of Glycogen Phosphorylase, $\mathrm{Ca}^{2+}$, and Mitogen-Activated Protein Kinases. J Pharmacol Exp Ther (2005) 313 (3):1305-13. doi: 10.1124/jpet.104.082743

39. Dixon CJ, Hall JF, Webb TE, Boarder MR. Regulation of Rat Hepatocyte Function by P2Y Receptors: Focus on Control of Glycogen Phosphorylase and Cyclic AMP by 2-Methylthioadenosine 5'-Diphosphate. J Pharmacol Exp Ther (2004) 311(1):334-41. doi: 10.1124/jpet.104.067744

40. Haussinger D, Busshardt E, Stehle T, Stoll B, Wettstein M, Gerok W. Stimulation of Thromboxane Release by Extracellular UTP and ATP From Perfused Rat Liver. Role of Icosanoids in Mediating the Nucleotide Responses. Eur J Biochem (1988) 178(1):249-56. doi: 10.1111/j.14321033.1988.tb14450.x

41. Koike M, Kashiwagura T, Takeguchi N. Gluconeogenesis Stimulated by Extracellular ATP is Triggered by the Initial Increase in the Intracellular $\mathrm{Ca}^{2+}$ Concentration of the Periphery of Hepatocytes. Biochem J (1992) 283 (Pt 1):265-72. doi: 10.1042/bj2830265

42. Staddon JM, McGivan JD. Effects of ATP and Adenosine Addition on Activity of Oxoglutarate Dehydrogenase and the Concentration of Cytoplasmic Free $\mathrm{Ca}^{2+}$ in Rat Hepatocytes. Eur J Biochem (1985) 151 (3):567-72. doi: 10.1111/j.1432-1033.1985.tb09141.x

43. Asensi M, Lopez-Rodas A, Sastre J, Vina J, Estrela JM. Inhibition of Gluconeogenesis by Extracellular ATP in Isolated Rat Hepatocytes. Am J Physiol (1991) 261(6 Pt 2):R1522-6. doi: 10.1152/ajpregu.1991 .261.6.R1522

44. Probst I, Quentmeier A, Schweickhardt C, Unthan-Fechner K. Stimulation by Insulin of Glycolysis in Cultured Hepatocytes is Attenuated by Extracellular ATP and Puromycin Through Purine-Dependent Inhibition of Phosphofructokinase 2 Activation. Eur J Biochem (1989) 182(2):387-93. doi: 10.1111/j.1432-1033.1989.tb14843.x

45. Gonzalez-Benitez E, Guinzberg R, Diaz-Cruz A, Pina E. Regulation of Glycogen Metabolism in Hepatocytes Through Adenosine Receptors. Role 
of Ca2+ and cAMP. Eur J Pharmacol (2002) 437(3):105-11. doi: 10.1016/ S0014-2999(02)01299-2

46. Guzman M, Velasco G, Castro J. Effects of Extracellular ATP on Hepatic Fatty Acid Metabolism. Am J Physiol (1996) 270(4 Pt 1):G701-7. doi: 10.1152/ajpgi.1996.270.4.G701

47. Cai Y, Li H, Liu M, Pei Y, Zheng J, Zhou J, et al. Disruption of Adenosine 2A Receptor Exacerbates NAFLD Through Increasing Inflammatory Responses and SREBP1c Activity. Hepatology (2018) 68(1):48-61. doi: 10.1002/ hep. 29777

48. Serhan N, Cabou C, Verdier C, Lichtenstein L, Malet N, Perret B, et al. Chronic Pharmacological Activation of $\mathrm{P} 2 \mathrm{Y}_{13}$ Receptor in Mice Decreases HDL-Cholesterol Level by Increasing Hepatic HDL Uptake and Bile Acid Secretion. Biochim Biophys Acta (2013) 1831(4):719-25. doi: 10.1016/ j.bbalip.2012.12.006

49. Fabre AC, Malaval C, Ben Addi A, Verdier C, Pons V, Serhan N, et al. P2 $\mathrm{Y}_{13}$ Receptor is Critical for Reverse Cholesterol Transport. Hepatology (2010) 52 (4):1477-83. doi: 10.1002/hep.23897

50. Blom D, Yamin TT, Champy MF, Selloum M, Bedu E, Carballo-Jane E, et al. Altered Lipoprotein Metabolism in $\mathrm{P}_{2} \mathrm{Y}_{13}$ Knockout Mice. Biochim Biophys Acta (2010) 1801(12):1349-60. doi: 10.1016/j.bbalip.2010.08.013

51. Zhang Y, Zhang T, Zhang C, Tang F, Zhong N, Li H, et al. Identification of Reciprocal Causality Between non-Alcoholic Fatty Liver Disease and Metabolic Syndrome by a Simplified Bayesian Network in a Chinese Population. BMJ Open (2015) 5(9):e008204. doi: 10.1136/bmjopen-2015-008204

52. Lim S, Kim JW, Targher G. Links Between Metabolic Syndrome and Metabolic Dysfunction-Associated Fatty Liver Disease. Trends Endocrinol Metab (2021) 32(7):500-14. doi: 10.1016/j.tem.2021.04.008

53. Pierantonelli I, Svegliati-Baroni G. Nonalcoholic Fatty Liver Disease: Basic Pathogenetic Mechanisms in the Progression From NAFLD to NASH. Transplantation (2019) 103(1):e1-13. doi: 10.1097/TP.0000000000002480

54. Liu IM, Tzeng TF, Tsai CC, Lai TY, Chang CT, Cheng JT. Increase in Adenosine $A_{1}$ Receptor Gene Expression in the Liver of StreptozotocinInduced Diabetic Rats. Diabetes Metab Res Rev (2003) 19(3):209-15. doi: $10.1002 / \mathrm{dmrr} .369$

55. Grden M, Podgorska M, Szutowicz A, Pawelczyk T. Diabetes-Induced Alterations of Adenosine Receptors Expression Level in Rat Liver. Exp Mol Pathol (2007) 83(3):392-8. doi: 10.1016/j.yexmp.2007.03.005

56. Das S, Seth RK, Kumar A, Kadiiska MB, Michelotti G, Diehl AM, et al. Purinergic Receptor X7 Is a Key Modulator of Metabolic Oxidative StressMediated Autophagy and Inflammation in Experimental Nonalcoholic Steatohepatitis. Am J Physiol Gastrointest Liver Physiol (2013) 305(12): G950-63. doi: 10.1152/ajpgi.00235.2013

57. Chatterjee S, Rana R, Corbett J, Kadiiska MB, Goldstein J, Mason RP. P2X7 Receptor-NADPH Oxidase Axis Mediates Protein Radical Formation and Kupffer Cell Activation in Carbon Tetrachloride-Mediated Steatohepatitis in Obese Mice. Free Radic Biol Med (2012) 52(9):1666-79. doi: 10.1016/ j.freeradbiomed.2012.02.010

58. Odashima M, Bamias G, Rivera-Nieves J, Linden J, Nast CC, Moskaluk CA, et al. Activation of $\mathrm{A}_{2 \mathrm{~A}}$ Adenosine Receptor Attenuates Intestinal Inflammation in Animal Models of Inflammatory Bowel Disease. Gastroenterology (2005) 129(1):26-33. doi: 10.1053/j.gastro.2005.05.032

59. Awad AS, Huang L, Ye H, Duong ET, Bolton WK, Linden J, et al. Adenosine $\mathrm{A}_{2 \mathrm{~A}}$ Receptor Activation Attenuates Inflammation and Injury in Diabetic Nephropathy. Am J Physiol Renal Physiol (2006) 290(4):F828-37. doi: 10.1152/ajprenal.00310.2005

60. Lukashev D, Ohta A, Apasov S, Chen JF, Sitkovsky M. Cutting Edge: Physiologic Attenuation of Proinflammatory Transcription by the Gs Protein-Coupled $\mathrm{A}_{2 \mathrm{~A}}$ Adenosine Receptor In Vivo. J Immunol (2004) 173 (1):21-4. doi: 10.4049/jimmunol.173.1.21

61. Zhou J, Li H, Cai Y, Ma L, Mathews D, Lu B, et al. Mice Lacking Adenosine $2 \mathrm{~A}$ Receptor Reveal Increased Severity of MCD-Induced NASH. J Endocrinol (2019) 243(3):199-209. doi: 10.1530/JOE-19-0198

62. Imarisio C, Alchera E, Sutti S, Valente G, Boccafoschi F, Albano E, et al. Adenosine $\mathrm{A}_{2 \mathrm{a}}$ Receptor Stimulation Prevents Hepatocyte Lipotoxicity and non-Alcoholic Steatohepatitis (NASH) in Rats. Clin Sci (Lond) (2012) 123 (5):323-32. doi: 10.1042/CS20110504

63. Alchera E, Rolla S, Imarisio C, Bardina V, Valente G, Novelli F, et al. Adenosine $\mathrm{A}_{2 \mathrm{a}}$ Receptor Stimulation Blocks Development of Nonalcoholic
Steatohepatitis in Mice by Multilevel Inhibition of Signals That Cause Immunolipotoxicity. Transl Res (2017) 182:75-87. doi: 10.1016/ j.trsl.2016.11.009

64. Peng Z, Borea PA, Varani K, Wilder T, Yee H, Chiriboga L, et al. Adenosine Signaling Contributes to Ethanol-Induced Fatty Liver in Mice. J Clin Invest (2009) 119(3):582-94. doi: 10.1172/JCI37409

65. Figler RA, Wang G, Srinivasan S, Jung DY, Zhang Z, Pankow JS, et al. Links Between Insulin Resistance, Adenosine $A_{2 B}$ Receptors, and Inflammatory Markers in Mice and Humans. Diabetes (2011) 60(2):669-79. doi: 10.2337/ db10-1070

66. Koupenova M, Johnston-Cox H, Vezeridis A, Gavras H, Yang D, Zannis V, et al. A2b Adenosine Receptor Regulates Hyperlipidemia and Atherosclerosis. Circulation (2012) 125(2):354-63. doi: 10.1161/ CIRCULATIONAHA.111.057596

67. Csoka B, Koscso B, Toro G, Kokai E, Virag L, Nemeth ZH, et al. $A_{2 B}$ Adenosine Receptors Prevent Insulin Resistance by Inhibiting Adipose Tissue Inflammation via Maintaining Alternative Macrophage Activation. Diabetes (2014) 63(3):850-66. doi: 10.2337/db13-0573

68. Johnston-Cox H, Koupenova M, Yang D, Corkey B, Gokce N, Farb MG, et al. The A2b Adenosine Receptor Modulates Glucose Homeostasis and Obesity. PLoS One (2012) 7(7):e40584. doi: 10.1371/journal.pone.0040584

69. Suresh RR, Jain S, Chen Z, Tosh DK, Ma Y, Podszun MC, et al. Design and In Vivo Activity of $\mathrm{A}_{3}$ Adenosine Receptor Agonist Prodrugs. Purinergic Signal (2020) 16(3):367-77. doi: 10.1007/s11302-020-09715-0

70. Fishman P, Cohen S, Itzhak I, Amer J, Salhab A, Barer F, et al. The $\mathrm{A}_{3}$ Adenosine Receptor Agonist, Namodenoson, Ameliorates Nonalcoholic Steatohepatitis in Mice. Int J Mol Med (2019) 44(6):2256-64. doi: 10.3892/ ijmm.2019.4364

71. Jain S, Pydi SP, Toti KS, Robaye B, Idzko M, Gavrilova O, et al. Lack of Adipocyte Purinergic P2 ${ }_{6}$ Receptor Greatly Improves Whole Body Glucose Homeostasis. Proc Natl Acad Sci USA (2020) 117(48):30763-74. doi: 10.1073/pnas.2006578117

72. Jain S, Pydi SP, Jung YH, Scortichini M, Kesner EL, Karcz TP, et al. Adipocyte P2Y14 Receptors Play a Key Role in Regulating Whole-Body Glucose and Lipid Homeostasis. JCI Insight (2021) 6(10):e146577. doi: 10.1172/jci.insight. 146577

73. Koyama Y, Brenner DA. Liver Inflammation and Fibrosis. J Clin Invest (2017) 127(1):55-64. doi: 10.1172/JCI88881

74. Schwabe RF, Tabas I, Pajvani UB. Mechanisms of Fibrosis Development in Nonalcoholic Steatohepatitis. Gastroenterology (2020) 158(7):1913-28. doi: 10.1053/j.gastro.2019.11.311

75. Ahsan MK, Mehal WZ. Activation of Adenosine Receptor A2A Increases HSC Proliferation and Inhibits Death and Senescence by Down-Regulation of P53 and Rb. Front Pharmacol (2014) 5:69. doi: 10.3389/fphar.2014.00069

76. Chiang DJ, Roychowdhury S, Bush K, McMullen MR, Pisano S, Niese K, et al. Adenosine 2A Receptor Antagonist Prevented and Reversed Liver Fibrosis in a Mouse Model of Ethanol-Exacerbated Liver Fibrosis. PLoS One (2013) 8(7):e69114. doi: 10.1371/journal.pone.0069114

77. Mustafa SJ, Nadeem A, Fan M, Zhong H, Belardinelli L, Zeng D. Effect of a Specific and Selective A(2B) Adenosine Receptor Antagonist on Adenosine Agonist AMP and Allergen-Induced Airway Responsiveness and Cellular Influx in a Mouse Model of Asthma. J Pharmacol Exp Ther (2007) 320 (3):1246-51. doi: 10.1124/jpet.106.112250

78. Dranoff JA, Ogawa M, Kruglov EA, Gaca MD, Sevigny J, Robson SC, et al. Expression of P2Y Nucleotide Receptors and Ectonucleotidases in Quiescent and Activated Rat Hepatic Stellate Cells. Am J Physiol Gastrointest Liver Physiol (2004) 287(2):G417-24. doi: 10.1152/ajpgi.00294.2003

79. Wu X, Wang Y, Wang S, Xu R, Lv X. Purinergic P2X7 Receptor Mediates Acetaldehyde-Induced Hepatic Stellate Cells Activation via PKC-Dependent GSK3beta Pathway. Int Immunopharmacol (2017) 43:164-71. doi: 10.1016/ j.intimp.2016.12.017

80. Huang C, Yu W, Cui H, Wang Y, Zhang L, Han F, et al. P2X7 Blockade Attenuates Mouse Liver Fibrosis. Mol Med Rep (2014) 9(1):57-62. doi: 10.3892/mmr.2013.1807

81. Le Guilcher C, Garcin I, Dellis O, Cauchois F, Tebbi A, Doignon I, et al. The P2X4 Purinergic Receptor Regulates Hepatic Myofibroblast Activation During Liver Fibrogenesis. J Hepatol (2018) 69(3):644-53. doi: 10.1016/ j.jhep.2018.05.020 
82. Andrade CM, Roesch GC, Wink MR, Guimaraes EL, Souza LF, Jardim FR, et al. Activity and Expression of Ecto-5'-Nucleotidase/CD73 are Increased During Phenotype Conversion of a Hepatic Stellate Cell Line. Life Sci (2008) 82(1-2):21-9. doi: 10.1016/j.lfs.2007.10.003

83. Fausther M, Sheung N, Saiman Y, Bansal MB, Dranoff JA. Activated Hepatic Stellate Cells Upregulate Transcription of Ecto-5'-Nucleotidase/CD73 via Specific SP1 and SMAD Promoter Elements. Am J Physiol Gastrointest Liver Physiol (2012) 303(8):G904-14. doi: 10.1152/ajpgi.00015.2012

84. Peng Z, Fernandez P, Wilder T, Yee H, Chiriboga L, Chan ES, et al. Ecto-5'Nucleotidase (CD73) -Mediated Extracellular Adenosine Production Plays a Critical Role in Hepatic Fibrosis. FASEB J (2008) 22(7):2263-72. doi: 10.1096/fj.07-100685

85. O'Rourke JM, Sagar VM, Shah T, Shetty S. Carcinogenesis on the Background of Liver Fibrosis: Implications for the Management of Hepatocellular Cancer. World J Gastroenterol (2018) 24(39):4436-47. doi: 10.3748/wjg.v24.i39.4436

86. Wei Q, Zhang Y, Sun L, Jia X, Huai W, Yu C, et al. High Dose of Extracellular ATP Switched Autophagy to Apoptosis in AnchorageDependent and Anchorage-Independent Hepatoma Cells. Purinergic Signal (2013) 9(4):585-98. doi: 10.1007/s11302-013-9369-0

87. Manzoor S, Idrees M, Ashraf J, Mehmood A, Butt S, Fatima K, et al. Identification of Ionotrophic Purinergic Receptors in Huh-7 Cells and Their Response Towards Structural Proteins of HCV Genotype 3a. Virol J (2011) 8:431. doi: 10.1186/1743-422X-8-431

88. Maynard JP, Lee JS, Sohn BH, Yu X, Lopez-Terrada D, Finegold MJ, et al. P2X3 Purinergic Receptor Overexpression Is Associated With Poor Recurrence-Free Survival in Hepatocellular Carcinoma Patients. Oncotarget (2015) 6(38):41162-79. doi: 10.18632/oncotarget.6240

89. Khalid M, Brisson L, Tariq M, Hao Y, Guibon R, Fromont G, et al. Carcinoma-Specific Expression of $\mathrm{P}_{2} \mathrm{Y}_{11}$ Receptor and its Contribution in ATP-Induced Purinergic Signalling and Cell Migration in Human Hepatocellular Carcinoma Cells. Oncotarget (2017) 8(23):37278-90. doi: 10.18632/oncotarget.16191

90. Xie R, Xu J, Wen G, Jin H, Liu X, Yang Y, et al. The P2 $Y_{2}$ Nucleotide Receptor Mediates the Proliferation and Migration of Human Hepatocellular Carcinoma Cells Induced by ATP. J Biol Chem (2014) 289 (27):19137-49. doi: 10.1074/jbc.M113.540047

91. Sun X, Han L, Seth P, Bian S, Li L, Csizmadia E, et al. Disordered Purinergic Signaling and Abnormal Cellular Metabolism are Associated With Development of Liver Cancer in Cd39/ENTPD1 Null Mice. Hepatology (2013) 57(1):205-16. doi: 10.1002/hep.25989

92. Ma XL, Shen MN, Hu B, Wang BL, Yang WJ, Lv LH, et al. CD73 Promotes Hepatocellular Carcinoma Progression and Metastasis via Activating PI3K/ AKT Signaling by Inducing Rap1-Mediated Membrane Localization of P110beta and Predicts Poor Prognosis. J Hematol Oncol (2019) 12(1):37. doi: 10.1186/s13045-019-0724-7

93. Shali S, Yu J, Zhang X, Wang X, Jin Y, Su M, et al. Ecto-5'-Nucleotidase (CD73) is a Potential Target of Hepatocellular Carcinoma. J Cell Physiol (2019) 234(7):10248-59. doi: 10.1002/jcp.27694

94. Bar-Yehuda S, Stemmer SM, Madi L, Castel D, Ochaion A, Cohen S, et al. The $\mathrm{A}_{3}$ Adenosine Receptor Agonist CF102 Induces Apoptosis of Hepatocellular Carcinoma via De-Regulation of the Wnt and NF-KappaB
Signal Transduction Pathways. Int J Oncol (2008) 33(2):287-95. doi: 10.3892/ijo_00000008

95. Cohen S, Stemmer SM, Zozulya G, Ochaion A, Patoka R, Barer F, et al. CF102 an $\mathrm{A}_{3}$ Adenosine Receptor Agonist Mediates Anti-Tumor and AntiInflammatory Effects in the Liver. J Cell Physiol (2011) 226(9):2438-47. doi: $10.1002 /$ jcp. 22593

96. Jacobson KA, Tosh DK, Jain S, Gao ZG. Historical and Current Adenosine Receptor Agonists in Preclinical and Clinical Development. Front Cell Neurosci (2019) 13:124. doi: 10.3389/fncel.2019.00124

97. Toti KS, Jain S, Ciancetta A, Balasubramanian R, Chakraborty S, Surujdin R, et al. Pyrimidine Nucleotides Containing a (S)-Methanocarba Ring as P2 6 Receptor Agonists. Medchemcomm (2017) 8(10):1897-908. doi: 10.1039/ C7MD00397H

98. Junker A, Renn C, Dobelmann C, Namasivayam V, Jain S, Losenkova K, et al. Structure-Activity Relationship of Purine and Pyrimidine Nucleotides as Ecto-5'-Nucleotidase (CD73) Inhibitors. J Med Chem (2019) 62(7):367795. doi: 10.1021/acs.jmedchem.9b00164

99. Jung YH, Yu J, Wen Z, Salmaso V, Karcz TP, Phung NB, et al. Exploration of Alternative Scaffolds for $\mathrm{P}_{2} \mathrm{Y}_{14}$ Receptor Antagonists Containing a Biaryl Core. J Med Chem (2020) 63(17):9563-89. doi: 10.1021/acs.jmedchem.0c00745

100. Jung YH, Jain S, Gopinatth V, Phung NB, Gao ZG, Jacobson KA. Structure Activity Relationship of 3-Nitro-2-(Trifluoromethyl)-2H-Chromene Derivatives as $\mathrm{P}_{2} \mathrm{Y}_{6}$ Receptor Antagonists. Bioorg Med Chem Lett (2021) 41:128008. doi: 10.1016/j.bmcl.2021.128008

101. Jung YH, Salmaso V, Wen Z, Bennett JM, Phung NB, Lieberman DI, et al. Structure-Activity Relationship of Heterocyclic P2Y14 Receptor Antagonists: Removal of the Zwitterionic Character With Piperidine Bioisosteres. J Med Chem (2021) 64(8):5099-122. doi: 10.1021/acs.jmedchem.1c00164

102. Gao ZG, Tosh DK, Jain S, Yu J, Suresh RR, Jacobson KA. A1 Adenosine Receptor Agonists, Antagonists, and Allosteric Modulators. Cham: Humana Press (2018).

103. Oliva P, Scortichini M, Dobelmann C, Jain S, Gopinatth V, Toti KS, et al. Structure-Activity Relationships of Pyrimidine Nucleotides Containing a 5'Alpha,Beta-Methylene Diphosphonate at the $\mathrm{P}_{2} \mathrm{Y}_{6}$ Receptor. Bioorg Med Chem Lett (2021) 45:128137. doi: 10.1016/j.bmcl.2021.128137

Conflict of Interest: The authors declare that the research was conducted in the absence of any commercial or financial relationships that could be constructed as a potential conflict of interest.

Publisher's Note: All claims expressed in this article are solely those of the authors and do not necessarily represent those of their affiliated organizations, or those of the publisher, the editors and the reviewers. Any product that may be evaluated in this article, or claim that may be made by its manufacturer, is not guaranteed or endorsed by the publisher.

Copyright (ㄷ) 2021 Jain and Jacobson. This is an open-access article distributed under the terms of the Creative Commons Attribution License (CC BY). The use, distribution or reproduction in other forums is permitted, provided the original author(s) and the copyright owner(s) are credited and that the original publication in this journal is cited, in accordance with accepted academic practice. No use, distribution or reproduction is permitted which does not comply with these terms. 